ElementerIs: Jurnal Ilmiah Pendidikan Dasar Islam

Volume 3 Nomor 1 Mei 2021

e-ISSN: 2655-6324

\title{
INTEGRASI NILAI-NILAI KEISLAMAN DALAM PEMBELAJARAN IPS PADA KURIKULUM 2013
}

\author{
Amirah Al May Azizah \\ Pascasarjana PGMI UIN Sunan Kalijaga Yogyakarta \\ e-mail: almayazizah97@gmail.com
}

Diterima: 12 Maret 2021 I Direvisi: 7 Mei 2021 I Disetujui: 21 Mei 2021 (C) 2021 Pendidikan Guru Madrasah Ibtidaiyah Fakultas Agama Islam Universitas Islam Malang

\begin{abstract}
Abstrak
Nilai-nilai Islam dibutuhkan dalam pendidikan. Nilai keislaman dalam pembelajaran IPS di MI diwujudkan dalam pola pembelajaran IPS secara keseluruhan dengan memperhatikan keberadaan pembelajaran IPS sebagai ilmu umum dan memperhatikan nilai-nilai keislaman peserta didik untuk membentuk karakter peserta didik. Penulisan ini bertujuan untuk mengetahui nilai keislaman yang terintegrasi dengan mata pelajaran umum khususnya ilmu sosial (IPS) di kelas III MIM Bendo PK Nogosari, dan pendidikan Islam berbasis integrasi keilmuan antara ilmu umum (akademik) dan ilmu agama (non akademik). Penelitian ini menggunakan penelitian kualitatif. Penelitian ini menggunakan teknik observasi, dokumentasi dan wawancara. Materi pada kompetensi dasar IPS kelas III di MIM Bendo PK Nogosari dapat diintegrasikan dengan nilai-nilai keislaman, misalnya materi tentang penampakan alam di kelas III, pendidik mengajak siswa untuk lebih bersyukur karena dalam hal ini mereka dapat melihat dan menikmati ciptaan Allah SWT yang juga menyisipkan kalimat thayyibah sesuai dengan perasaannya. Selain itu nilai-nilai yang bisa diambil dalam materi penampakan alam ini adalah nilai syukur. Kemudian materi bergaul dengan tetangga yang meliputi akhlak dalam bersosialisasi dengan manusia lain juga telah dijelaskan dalam Q.S Luqman ayat 18. Masih banyak materi lain dalam kompetensi dasar IPS kelas III yang dapat diintegrasikan dengan nilai-nilai keislaman.
\end{abstract}

Kata Kunci: nilai-nilai islam, pembelajaran ilmu sosial

\begin{abstract}
Islamic values are needed in education. Islamic values in social studies learning at MI is manifested in the overall social studies learning pattern by paying attention to the existence of social studies learning as a general science and paying attention to the Islamic valuesof students to form character students. This writing aims to determine the value of Islam that is integrated with general subjects, especially social science (IPS) in class III MIM Bendo PK Nogosari, and Islamic education based on scientific integration between general science (academic) and religious science (non-academic). This research uses qualitative research. This research uses observation, documentation and interview techniques. Material in the basic competencies of social science class III at MIM Bendo PK Nogosari can be integrated with Islamic values, for example material about natural appearances in class III, educators invite students to be more grateful because in this case, they can see and enjoy the creation of Allah SWT, who also insert the thayyibah sentence according to what he feels. In addition, the values that can be taken in this natural appearance material are the value of gratitude. Then the material of getting along with neighbors, which includes morals in socializing with other humans, has also been described in Q.S Luqman verse 18. There are still many other materials in the basic competences of IPS class III that can be integrated with Islamic values.
\end{abstract}

Keyword: islamic values, social sciences learning 


\section{PENDAHULUAN}

Pendidikan pada hakikatnya merupakan proses perubahan kebiasaan, keterampilan, dan kompetensi. Pola perubahan pendidikan pada era abad 21 saat ini merupakan salah satu ciri adanya globalisasi. Perubahan dalam hal ini memungkinkan untuk stagnan dalam perilaku yang terjadi sebagai output dari pengalaman maupun pembiasaan. Pendidikan dalam era ini merupakan suatu pembelajaran yang ditandai dengan mengasah keterampilan 4C (critical thinking, communication, creative, and collaboration) yaitu berfikir kritis, berkomunikasi dengan baik, kreatif, dan mampu bekerja sama dengan baik. Pendidikan saat ini memiliki beberapa karakteristik seperti pengintegrasian ilmu, berfikir kritis, kreatif dan inovatif, serta komunikatif dan memiliki jiwa kolaboratif (Hasibuan \& Prastowo, 2019).

Pendidikan dalam prosesnya merupakan faktor utama dalam membentuk individu seseorang. Sebagaimana Rasulullah SAW bersabda bahwa pendidikan merupakan keharusan bagi setiap umat manusia, oleh karenanya pendidikan berperan sangat penting dalam membentuk keberadaan dirinya dalam di kancah kehidupan global di era ini. Dengan pendidikan, seseorang akan mampu mengembangkan dirinya untuk membentuk kepribadian, spiritual, moral dan akhlak yang baik, serta mampu hidup dalam lingkungan sosialnya. Selain pendidikan, dalam membentuk peserta didik agar memiliki karakter religius, peran lingkungan sosial dalam proses sosial sangat penting, karena melalui lingkungan sosialnya dalam interaksi dengan teman sebayanya, peserta didik dapat belajar dan mencerminkan karakternya di lingkungan sekitarnya (Hasanah \& Munastiwi, 2019).

Lingkungan sosial dalam hal ini yaitu lingkungannya dalam proses pembelajaran berlangsung. Pendidikan di era ini memerlukan peran agama, hal ini diperlukan karena untuk mencegah hal-hal yang menyimpang di kemudian hari. Misalnya pelajar di Indonesia saat ini seringkali menyebabkan kegaduhan yang membuat masyarakat resah dan lingkungan sekitarnya seperti pelajar yang tawuran, melakukan pembulian terhadap teman sebayanya, mengkonsumsi narkoba, dan lain sebagainya. Problematika yang terjadi di kelas III MIM Bendo PK Nogosari yakni terdapat pada peserta didik, terdapat beberapa siswa yang trouble maker sehingga memberikan dampak terhadap lingkungan teman kelasnya. Selain itu, di MIM Bendo PK Nogosari adalah sekolah yang berbasis madrasah dan mengkonstruksi nilai-nilai keislaman merupakan kewajiban bagi pendidik dalam mengintegrasikan nilai keislaman dengan pembelajaran terten tu. Maka untuk mencegah hal-hal tersebut, perlu adanya penanaman nilai-nilai 
agama atau keislaman sejak usia dasar dalam proses pembelajaran.

Pada dasarnya manusia adalah makhluk sosial yang saling berhubungan antara satu dengan yang lainnya. Dalam pola interaksinya dengan manusia lainnya maka seharusnya dibiasakan dengan mengenal dan mengimplementasikan nilai-nilai keislaman. Dalam hal ini, pembelajaran IPS merupakan pembelajaran yang mampu mengintegrasikan atau menghubungkan dengan nilai-nilai islam. Demikian agar materi dalam pembelajaran IPS tidak akan terlepas dari nilai-nilai agama. Pembelajaran IPS adalah pembelajaran yang mempelajari tentang tata kehidupan antar manusia dalam berbagai aktivitasnya. Maka tujuan dari pembelajaran IPS yakni untuk menciptakan warga negara yang agamis, kritis, kreatif dan peduli terhadap lingkungannya (Abdul Wahid, 2019).

Berdasarkan peryataan tersebut, maka mengintegrasikan nilai-nilai keislaman yang dapat membentuk karakter yang religius sangatlah penting untuk di kaitkan dengan pembelajaran IPS khususnya di jenjang usia dasar. Selain pembelajaran IPS, nilai-nilai keislaman juga dapat dihubungkan dengan pembelajaran lainnya seperti pembelajaran IPA, Matematika, Pendidikan Kewarganegaraan, dan sebagainya. Berdasarkan pernyataan tersebut dalam penelitian terdahulu mengenai integrasi nilai-nilai keislaman dalam pembelajaran biologi di SMA Islam Al Ulum Terpadu Medan" (Amri \& Rasyidin \& Imran, 2017). Hasil dalam penelitian tersebut yaitu strategi proses memadukan nilai keislaman dalam pembelajaran biologi di SMA Islam Al Ulum Terpadu Medan sebatas pada menelusuri ayat-ayat yang berkaitan dengan materi pembelajaran yang disajikan, strategi pelaksanaan dalam mengintegrasikan nilai keislamannya yakni dengan model integrasi-interkoneksi yaitu mengaitkan ayat ayat Al-Qur'an dengan materi yang tersaji.

Adapun dalam penelitian terdahulu mengenai "Integrasi Matematika dan Islam dalam Pembelajaran Matematika" (Samsul Maarif, 2015). Hasil kajian literatur dalam penelitian tersebut membahas tentang ke-Esa-an dan sifat-sifat Allah dengan konsep limit, sikap berserah diri kepada Allah menggunakan konsep barisan dan pecahan. Konsep-konsep dalam matematika tersebut dapat dijadikan acuan untuk menyisipkan nilai-nilai keislaman dalam proses pembelajaran. Berdasarkan uraian tersebut, nilai-nilai keislaman sangatlah penting untuk di integrasikan ke dalam pembelajaran, khususnya pembelajaran IPS di jenjang usia dasar. Hal ini dibutuhkan untuk membentuk moral dan karakter religius peserta didik sejak dini, agar terciptanya individu yang berkarakter spiritual dan mampu hidup di tengah di kancah global saat ini. Dalam penelitian ini, penulis fokus pada proses pembelajaran IPS yang 
terintegrasi dengan nilai islam di MIM PK Bendo Nogosari. Penulis memilih di MIM PK Bendo kecamatan Nogosari kabupaten Boyolali. Sebuah madrasah swasta yang telah mengintegrasikan nilai-nilai keislaman dengan pembelajaran, khususnya kompetensi dasar pembelajaran IPS dalam pembelajaran tematik.

\section{METODE}

Penelitian yag dilakukan merupakan jenis penelitian kualitatif. Penelitian kualitatif dilakukan dengan mendeskripsikan suatu keadaan yang sebenarnya dan dapat mengungkap informasi kualitatif secara teliti dan prosesnya yang deskripsianalisis (Anggito \& Setiawan, 2018). Penelitian ini bersifat deskriptif analitik. Adapun penelitian ini menggunakan teknik observasi, dokumentasi dan teknik wawancara. Subjek penelitian dalam penelitian ini yaitu ibu Dwi Nur Nitasari, S.Pd selaku guru kelas 3 di MIM Bendo PK Nogosari. Data yang dihasilkan diolah sedemikian rupa, kemudian data disajikan dan selanjutnya data tersebut disimpulkan dan diverifikasi (Ahmad Rijali, 2018). Analisis data dalam penelitian ini menggunakan model Miles and Hubermen yang meliputi reduksi data, penyajian data, dan penarikan kesimpulan.

\section{HASIL DAN PEMBAHASAN}

Berdasarkan data hasil wawancara, observasi, serta dokumentasi didapatkan data yang meliputi 1) Pendidikan nilai Islam di MIM Bendo PK Nogosari, 2) Integrasi Nilai-Nilai Keislaman di MIM Bendo PK Nogosari, 3) pembelajaran IPS di SD/MI dalam kurikulum 2013 di MIM Bendo PK Nogosari, dan 4) implementasi nilai ke-Islaman dalam pembelajaran IPS di MIM Bendo PK Nogosari. Data tersebut dipaparkan sebagai berikut.

\section{Pendidikan Nilai Islam di MIM Bendo PK Nogosari}

Nilai merupakan sesuatu yang abstrak, yang berarti sifat dan ciri-cirinya ttindakan, norma serta keyakinan (Ade Imelda Frimayanti, 2017). Nilai dijadikan sebagai standar perilaku seseorang untuk dijadikan patokan sesuai dengan nilainilai yang telah diyakini masing-masing individu. Adapun definisi nilai keislaman yaitu sepaket keteguhan seseorang yang sesuai dalam ajaran islam dan menciptakan insan kamil (Nugroho \& Mustaidah, 2017). Dalam hal ini, nilai sejalan dengan tujuan pendidikan islam yaitu antara lain; menambah wawasan spiritual secara mendalam, kemudian mengembangkan pemikiran secara logika keislaman dalam kehidupan milenial. Selanjutnya mengembangkan potensi peserta didik dalam menghargai kebudayaan islam di masa Rasulullah SAW diatas kebudayaan lainnya, mendorong kecakapan dalam perkembangan emosi melalui pengalaman 
nyata sehingga peserta didik dapat mengembangkan kemampuan kreativitasnya, serta mengetahui norma dan nilai islam yang benar atau yang salah. (Bagus Fauzi, 2020).

Nilai juga behubungan erat terhadap aktivitas seseorang. Nilai-nilai bersumber pada agama dan tradisi humanistik (Halimatussa'diyah, 2020). Adapun nilai yang harus ditanamkan kepada peserta didik yaitu nilai spiritual. Nilai spiritual harus dimiliki dalam hati nurani, dan nilai spiritual sebagai landasan moral seseorang, maka peserta didik wajib memiliki nilai spiritual, karena dengan memiliki nilai spiritual peserta didik akan dijauhkan dengan hal negatif dan menyimpang. Selanjutnya nilai tanggungjawab, nilai dalam menghargai orang lain, nilai amanah, nilai kerjasama dan demokratis. (Pasiska, 2019). Sebagaimana telah dipaparkan mengenai makna nilai, nilai keislaman membantu dalam mengembangkan sosialisasi serta meningkatkan kekompakan dalam berinteraksi maupu berkomunikasi dengan baik.

Sehubungan dengan hal tersebut, berdasarkan wawancara guru kelas III di MIM Bendo PK Nogosari, tujuan dari penanaman nilai keislaman dalam pembelajaran yaitu agar memperkuat keimanan dan ketakwaan peserta didik sehingga dalam kehidupan sehari-hari siswa akan terbiasa dengan nilai-nilai yang telah diajarkan. Esensi dari pendidikan islam itu sendiri adalah Al-Qur'an dan Hadis, diatas kedua pilar tersebut maka terwujudlah konsep pendidikan islam sesuai dengan ajaran islam (Haidar Putra Daulay, 2014). Nilai-nilai pendidikan islam terdapat tiga macam, antara lain; (1) nilai ibadah yaitu nilai suatu perwujudan dari pengabdian diri kepada Allah SWT, (2) nilai perilaku/sikap, dalam hal ini akhlak tidak dapat terpisahkan dari spiritualitas, apabila menurut agama suatu akhlak seseorang baik, maka menurut agama juga baik, (3) nilai iman yaitu sesuatu yang diyakini dalam hati dan dan diucapkan oleh mulut kemudian terwujud dalam perbuatan (Indana \& Fatiha \& Ba'dho, 2020).

Prinsip-prinsip pendidikan islam merupakan proses perubahan dan penghayatan yakni proses pelaksanaannya harus berkelanjutan dan bertahap serta tersusun secara sistematis dan terstruktur. Prinsip selanjutnya ada pada diri peserta didik yaitu diberikan kepada anak didik agar mengembangkan potensi spiritualnya, kemudian menuju kesempurnaan agar menghasilkan individu yang berakhlaqul karimah. Berdasarkan penelitian sebelumnya oleh (Nurul Jempa, 2018) yang membahas tentang nilai-nilai keislaman. Dalam penelitian tersebut, wujud nilai keislaman dapat diimplementsikan dalam kehidupan manusia, karena nilai-nilai keislaman merupakan memiliki pengaruh yang besar terhadap lingkungan sosial manusia. 
Demikian pada hakikatnya, nilai keislaman merupakan prinsip kehidupan serta ajaran mengenai bagaimana manusia hidup dan menjalankan kehidupannya. Berdasarkan uraian tersebut maka, fungsi keberadaan pendidikan islam yakni untuk menuntun seluruh aktivitas kehidupan yang disesuaikan dengan ketentuan yang telah ditetapkan Allah SWT baik kehidupan pribadi seseorang maupun secara sosial dalam pengelolaan dan pengembangan sumber daya alam sebagai bentuk pengabdian diri kepada Allah SWT (Hanafi \& Adu \& Zainuddin, 2019). Selain fungsi pendidikan islam, tugas pendidikan islam yaitu membantu peserta didik dalam membina peserta didik dalam ketaatan kemudian dijabarkan dalam mengarahkan kompetensi iman, islam, ihsan, agar nilai-nilai pendidikan islam berguna maka harus di implementasikan dengan baik.

\section{Integrasi Nilai-Nilai Keislaman di MIM Bendo PK Nogosari}

Integrasi memiliki makna 'keterkaitan' dan 'keterhubungan'. Secara umum, integrasi berarti rangkaian berbagai peristiwa menjadi satu kesatuan utuh. Dalam struktur keilmuan, integratif juga diartikan sebagai usaha terencana dalam menyatukan suatu hubungan pada aspek yang berbeda namun menjadi keterpaduan yang baik. Integrasi nilai-nilai islam dalam pembelajaran hendaknya diterapkan sejak berada di sekolah dasar, karena semakin tinggi ilmu seseorang terlebih ilmu-ilmu umum maka semakin berkurang juga pengamalan nilai-nilai islam seseorang. Konsep integrasi nilai-nilai keislaman dibutuhkan agar dapat dimaksimalkan dalam bentuk nyata perilaku peserta didik. Islam dan ilmu dapat dijadikan perpaduan dari segala aspek kehidupan nyata peserta didik. Tujuan integrasi dalam pembelajaran yaitu antara lain; mengoptimalkan pemahaman konsep secara lebih bermakna, mengembangkan kompetensi serta mengolah informasi dengan baik dan tepat, mengembangkan kebiasaan positif dari nilai-nilai luhur yang ditanamkan, kemudian dapat mengoptimalkan kecakapan dalam berinteraksi sosial. Demikian dengan adanya tujuan tersebut, maka integrasi nilainilai islam diharapkan dapat diimplementasikan dalam kehidupan nyata.

Berdasarkan uraian diatas, adapun wujud dari integrasi nilai-nilai keislaman dalam pembelajaran kelas III di MIM Bendo PK Nogosari antara lain; berdoa sebelum dan sesudah pembelajaran, mengucapkan dan menjawab salam, membiasakan peserta didik bertutur kata dengan baik dan diajarkan mel

alui contoh dan teladan para guru, muraja'ah surat dalam Al-Qur'an setiap pagi sebelum pembelajaran dimulai, dan melaksanakan sholat dhuha, serta menutup aurat. Dalam hal menutup aurat, di MIM Bendo PK Nogosari diwajibkan, karena memang di madrasah wajib memakai atribut bernuansa islami. Selain itu, pengamalan nilai-nilai keislaman tidak hanya diberikan saat pembelajaran saja, 
demikian dapat pula diaplikasikan di lingkungan sekolah dalam bentuk peraturan atau ekstrakulikuler, misalnya peraturan/kewajiban sholat berjamaah di sekolah, atau hafalan ayat-ayat Al-Qur'an dan Hadits, dalam bentuk ekstrakulikuler wajib seperti ekstra qira'ah, khitobah, dan ekstrakulikuler lainnya yang menunjang pengamalan nilai-nilai islam di madrasah.

Selanjutnya integrasi nilai keislaman dalam kegiatan pembelajaran di madrasah dilakukan dengan mentransformasikan materi-materi pelajaran dengan pendekatan nilai-nilai keislaman melalui metode dan model pembelajaran atau lainnya. Proses pembelajaran di kelas III MIM Bendo PK Nogosari, guru menggunakan metode ceramah dan kontekstual dalam mengintegrasikan nilainilai keislaman dalam pembelajarannya. Adapun model pembelajaran yang terintegrasi antara lain; jaring laba-laba yaitu model pembelajaran yang menggunakan pendekatan tematik, kemudian model terhubung yaitu model pembelajaran yang menghubungkan beberapa keterampilan, sikap dan konsep, selanjutnya model pembelajaran terpadu yaitu model pembelajaran dengan menggabungkan beberapa disiplin ilmu atau mata pelajaran dalam satu tema (Uum Murfiah, 2017). Selain model pembelajaran, terdapat metode pembelajaran yang terintegrasi.

Metode pembelajaran adalah cara atau teknik mengajar pendidik dalam kegiatan pembelajaran. (Bagus Fauzi, 2020) mengemukakan beberapa metode pembelajaran terpadu yakni antara lain; metode moralizing atau metode yang digunakan pendidik dalam memotivasi dan menasihati peserta didik yaitu peserta didik diajarkan secara langsung mengenai nilai-nilai keislaman melalui ceramah, atau pidato dengan cara memberi motivasi dan nasihat untuk dijadikan pedoman hidup peserta didik. Selain itu metode pembelajaran alaissezfaireattitude atau disebut juga metode yang memberi kebebasan peserta didik untuk mengeksplor nilai nilai yang akan dijadikan pegangan. Dalam hal ini pendidik memberikan arahan kemudian peserta didik bebas menentukan selama tidak keluar dari penyimpangan nilai. Selanjutnya metode modelling yaitu pendidik sebagai role model yang memberi contoh kepada peserta didik mengenai nilai-nilai keislaman yang diterapkan dalam kegiatan sehari-hari.

Berdasarkan penelitian sebelumnya oleh (Pudin Saripudin, 2018) mengenai pengitegrasian nilai islam dalam mata pelajaran sains di SDN Sadamantra Kuningan. Dalam penelitian ini, di sekolah dasar negeri sadamantra tersebut telah mengintegrasikan nilai keislaman dalam pembelajaran ipa, yaitu dengan manyampaikan intisari dari dalil-dalil dalam Al-Qur'an yang dipahami para pendidik, hal ini dikarenakan para pendidik di sekolah tersebut tidak melafalkan 
dalil naqli secara utuh, dan para pendidik mayoritas tidak memiliki latar belakang pendidikan agama islam., oleh karena itu integrasi dalam pembelajaran ipa di sekolah tersebut dapat dikatakan sederhana dan simpel. Berdasarkan uraian tersebut, maka integrasi nilai-nilai keislaman dalam pembelajaran tertentu tergantung pada metode yang diajarkan pendidik dalam proses kegiatan pembelajaran.

\section{Pembelajaran IPS di SD/MI dalam Kurikulum 2013 di MIM Bendo PK Nogosari}

Dalam kurikulum 2013, pembelajaran pada tiap-tiap mata pelajaran dilakukan dengan pendekatan tematik integratif, serta proses pembelajaran terpusat pada peserta didik. (Yulia Siska, 2016) mengemukakan bahwa pembelajaran IPS di SD/MI bertujuan untuk membentuk peserta didik menjadi individu yang mempunyai keterampilan (skill), wawasan yang luas (knowledge), serta memiliki nilai dan sikap sebagai warga negara yang baik. Aspek sosial yang diajarkan dalam pembelajaran IPS membutuhkan pembahasan dari berbagai disiplin keilmuan.

Rumusan IPS berdasarkan fenomena sosial dan realita sosial yang dirumuskan melalui pendekatan interdisipliner (Lisnawati, 2018). Kaitannya dengan inovasi materi pokok IPS di SD/MI yang berbasis integrasi maksudnya adalah menggabungkan serta mengaitkan materi pokok IPS dengan mata pelajaran lainnya. Contoh misalnya, materi mengenai keanekaragaman budaya di Indonesia seperti alat musik tradisional berbagai daerah, praktek dengan permainan alat musik tradisional disini adalah termasuk materi pokok SBdP (Seni Budaya dan Prakarya) di SD/MI.Adapun karakteristik pembelajaran IPS dilihat dari tujuan pembelajaran IPS yaitu meliputi aspek sosial, aspek intelektual dan aspek individu (Ahmad Susanto, 2016).

Berdasarkan hal tersebut diatas, dalam pembelajaran tematik terdapat berbagai kompetensi dasar dalam pembelajaran, di kelas III MIM Bendo PK Nogosari, guru kelas III menegaskan bahwa pembelajaran yang menonjol dalam mengintegrasikan nilai keislaman yaitu pembelajaran IPS dan pembelajaran PPKN. Bahwa pembelajaran IPS terdapat beberapa materi yang terintegrasi dengan nilai keislaman, sedangkan pembelajaran PPKN terintegrasi dengan nilai karakter yang terikat dengan nilai keislaman.

Pembelajaran IPS merupakan hubungan dari berbagai disiplin ilmu sosial seperti ilmu sejarah, geografi, antropologi (budaya), ilmu ekonomi, dan ilmu sosial. Misalnya geografi di SD/MI mempelajari tentang peta dan globe atau letak geografi suatu negara, dan kenampakan alam yang terjadi di Indonesia. Ilmu sejarah di 
SD/MI membahas tentang perjuangan para pahlawan dalam melawan penjajahan, serta mempelajari tokoh-tokoh nasional yang memperjuangkan kemerdekaan Indonesia. Ilmu budaya di SD/MI mempelajari tentang keragaman budaya di Indonesia seperti; alat musik tradisional, pakaian adat berbagai suku di Indonesia, tarian-tarian adat, rumah adat dan sebagainya. Kemudian ilmu sosial di SD/MI mempelajari tentang kerukunan antar warga di lingkungan masyarakat, dan memahami hak kewajiban sebagai bagian dari masyarakat. Ilmu ekonomi di SD/MI yang mempelajari tentang profesi dan jasa, nilai mata uang, dan transaksi jual beli yang terjadi di lingkungan masyarakat. Materi-materi yang terdapat dalam pembelajaran IPS di SD/MI tersebut, pada kurikulum 2013 tercakup dalam pembelajaran tematik.

Berdasarkan penelitian sebelumnya oleh (Tika M. \& Melinedri \& Alfiana A. \& Siti H.H, 2020) membahas tentang mengintegrasikan pembelajaran IPS dalam K13 di sekolah dasar. Dalam penelitian ini, pembelajaran IPS memiliki posisi yang sama dengan mata pelajaran yang lain, walaupun pembelajaran dilakukan dengan cara tematik, namun kompetensi dasar IPS tetap berdiri sendiri. Berdasarkan uraian tersebut, maka pembelajaran IPS di SD/MI pada kurikulum 2013 termasuk dalam pembelajaran tematik, akan tetapi setiap mata pelajaran didalamnya tidak terpisahkan dari kompetensi dasarnya.

\section{Implementasi Nilai Keislaman dalam Pembelajaran IPS di MIM Bendo PK Nogosari}

Kompetensi dasar dalam pembelajaran IPS di jenjang usia dasar terdapat pada pembelajaran tematik, kemudian diterapkan dengan mengintegrasikan nilainilai keislaman sebagai pedoman peserta didik dalam berperilaku dan bertindak. Adapun integrasi pembelajaran IPS di SD/MI dalam kurikulum 2013yang kaitannya dengan nilai-nilai keislaman, maksudnya dalam hal ini yaitu dengan menggabungkan berbagai cabang ilmu-ilmu umum salahsatu contohnya seperti ilmu sosial/IPS dengan ilmu agama. Integrasi-interkoneksi pada pembelajaran IPS yang kaitannya dengan nilai agama khususnya untuk tingkat MI/Madrasah Ibtidaiyah, nilai keislaman diartikan sebagai nilai yang berasal dari agama islam sehingga sangat sesuai secara pelaksanaannya dengan lembaga madrasah ibtidaiyah (Lisnawati, 2018). Proses integrasi nilai islam dengan pembelajaran IPS di MI tidak mungkin terlepas dari keterpaduannya terhadap nilai-nilai keislaman. Ada beberapa alasan perlunya spiritualitas disertakan dalam pembelajaran IPS, menurut (Listinawati, 2018) alasan tersebut antara lain sebagai berikut;karena agama merupakan sistem nilai yang terverifikasi sebagai nilai utama dalam kehidupan masyarakat. 
Hal tersebut dapat membentuk martabat yang baik atas dasar agama, dan sebagai suatu kekuatan untuk menggerakkan sosial. Selanjutnya karena pemahaman lingkungan sosial masyarakat dalam pembelajaran IPS tidak dapat terlepaskan dari nilai-nilai dan dasar agama, karena fenomena yang terjadi dalam masyarakat selalu terikat dengan nilai sosial masyarkat, dan agama sebagai pembentuk sistem nilai yang paling besar. Kemudian agama merupakan pendidikan moral masyarakat secara individu maupun sosial, sehingga ketika pembelajaran IPS berada diposisi sebagai komponen pendidikan moral/karakter, maka tidak mugkin terlepas dari peran spiritualitas dan agama. Dengan keterpaduan tersebut, nilai sosial yang dimaknai secara mendalam oleh siswa tidak hanya bersumber dari nilai sosial, namun juga nilai sosial yang memiliki landasan nilai spiritual.

Selanjutnya dalam implementasi pembelajaran IPS yang terintegrasi dengan nilai keislaman, di kelas III MIM Bendo PK Nogosari implementasinya tergantung materi, sebagai contohnya materi kenampakan alam di kelas III, pendidik bisa mengajak peserta didik untuk lebih bersyukur karena dalam hal ini, dapat melihat dan menikmati ciptaan Allah SWT, yang juga menyisipkan kalimat thayyibah sesuai dengan apa yang dirasakannya. Selain itu, nilai-nilai yang dapat diambil dalam materi kenampakan alam ini yaitu nilai syukur, nilai moral dengan mencintai alam semesta dan melestarikannya dilakukan dengan tidak membuang sampah sembarangan, tidak menebang pohon, dan sebagainya. Dalam hal lain, misalnya materi rukun dengan tetangga yang termasuk seperti akhlak dalam bersosialisasi dengan manusia lain juga sudah dijelaskan dalam Q.S Luqman ayat 18 yang artinya; "janganlah kamu memalingkan wajah dari manusia (karena sombong) dan janganlah berjalan di bumi dengan angkuh. Sungguh, Allah tidak menyukai orang-orang yang sombong dan membanggakan diri”. Materi lainnya dalam kompetensi dasar IPS masih banyak yang dapat di integrasikan dengan nilai keislaman. Nilai keislaman juga meliputi nilai-nilai karakter yang terkandung dalam materi pokok IPS, karena dengan ditanamkannya nilai-nilai karakter yang terdapat dalam materi ajar IPS, maka akan membentuk moral serta akhlak yang mulia bagi peserta didik.

Nilai yang penting bagi perkembangan peserta didik, salah satu contohnya adalah nilai kejujuran. Di sekolah pengaplikasian nilai sosial kejujuran dengan nilai spiritual misalnya adanya 'kantin kejujuran'. Kantin kejujuran mengajarkan peserta didik untuk jujur dalam membeli dan membayar sesuai harga yang tertulis. Tidak hanya nilai kejujuran, dasar perilaku kejujuran peserta didik karena adanya dorongan nurani spiritualnya, mereka merasa terawasi perilakunya oleh Tuhannya 
(Nursid Sukmaatmaja, 2016). Merujuk pada pendapat (Lisnawati, 2018) bahwa materi IPS di MI tidak semua bisa diintegrasikan dengan nilai-nilai keislaman oleh pendidik, karena dalam hal ini belum adanya modul sebagai standar yang dapat dijadikan pedoman pendidikdalam memuat materi IPS dengan terintegrasi nilai keislaman.

Maka hal tersebut berakibat bahwa proses pengintegrasian dilimpahkan kepada pendidik, karena apabila tidak ada modul pedoman, tidak semua pendidik yang mampu memahami nilai-nilai islam dengan baik. Maka dalam hal ini belum adanya aturan mengenai kebijakan pembelajaran yang integratif dengan nilai keislaman. Namun dalam pelaksanaannya, di madrasah ibtidaiyah peran pendidik setidaknya dapat mengaitkan nilai-nilai keislaman dalam materi ajar IPS pada buku tematik, misalnya materi ips kelas III tentang keragaman suku bangsa di Indonesia. Dalam Al-Qur'an juga dijelaskan dalam Q.S Al-Hujurat ayat 13 yang artinya;"wahai manusia! sesungguhnya kami telah menciptakan kalian menjadi lakilaki dan perempuan, dan (dengan menciptakan manusia berpasangan) kami telah jadikan kalian berbangsa-bangsa dan bersuku-suku agar kalian saling mengenal. Sesungguhnya yang paling bertakwa diantara kalian di sisi Allah adalah yang paling bertakwa. sesungguhnya Allah Maha Mengetahui, Mahateliti".

Adapun kendala dan hambatan dalam mengintegrasikan nilai keislaman dengan pembelajaran IPS di kelas III MIM Bendo PK Nogosari yaitu ada pada diri peserta didik sendiri yakni terkadang ada beberapa peserta didik yang cenderung sulit diatur dalam pelaksanaan pembelajarannya dan membuat suasana pembelajaran kurang kondusif sehingga proses pengintegrasian nilai keislaman tidak tersampaikan dengan baik dan maksimal.

Berdasarkan penelitian sebelumnya oleh (Munawarah \& Nurhayati Ali, 2016) membahas mengenai implementasi nilai islam dalam pembelajaran umum. Dalam penelitian ini, dapat disimpulkan bahwa guru mata pelajaran umum mengajarkan materi dengan menerapkan nilai-nilai ajaran islam sebagai ciri khas lembaga pendidikan pondok pesantren, hal ini pihak yayasan pesantren membuat kurikulum yang sesuai dengan ajaran islam. Berdasarkan uraian tersebut, nilainilai keislaman telah diintegrasikan dengan disiplin ilmu seperti pembelajaran IPS khususnya di lembaga pendidikan yang berbasis madrasah seperti madrasah ibtidaiyah.

\section{SIMPULAN}

Demikian dapat disimpulkan bahwa nilai-nilai keislaman yang terintegrasi dengan kompetensi dasar pembelajaran IPS di kelas III MIM Bendo PK Nogosari 
tidak terlepas dari peran pendidik. Tujuan dari integrasi nilai-nilai keislaman yakni agar peserta didik dalam mempelajari ilmu pengetahuan tidak melepaskan nilainilai keislaman sebagai sebagai pegangan dalam menjalani kehidupan dan bersosialisasi dengan masyakarat.

Dalam penulisan ini diperlukan penelitian lanjutan mengenai nilai-nilai keislaman dengan disiplin ilmu lainnya khususnya di lembaga pendidikan yang berbasis madrasah seperti madrasah ibtidaiyah, madrasah tsanawiyah, atau madrasah aliyah.

\section{DAFTAR RUJUKAN}

Amri, M. N., \& Al-Rasyidin, \& Ali, I. 2017. Integrasi Nilai-Nilai Keislaman dalam Pembelajaran Biologi di SMA Islam Al-Ulum Terpadu Medan. Jurnal: Volume 1 Nomor 4 Oktober-Desember 2017. Edu Religia.

Anggito, A., \& Johan, S. 2018. Metodologi Penelitian Kualitatif. Cet I. Sukabumi: CV. Jejak.

Daulay, H., P. 2014. Pendidikan Islam dalam Perspektif Filsafat. Cet I. Jakarta: Kencana.

Fauzi, B. 2020. Integrasi Pendidikan Nilai-Nilai Islam dalam Pembelajaran. Jurnal: Volume 1 Nomor 2 Juli 2020. eL-SANTRY.

Frimayanti, A., I. 2017. Implementasi Pendidikan Nilai dalam Pendidikan Agama Islam. Jurnal: Volume 8 Nomor 2. At-Tadzkiyah Jurnal Pendidikan Islam.

Halimatussa'diyah. 2020. Nilai-Nilai Pendidikan Islam Multikultural. Surabaya: CV. Jakad Media Publishing.

Hanafi, H., \& La Adu, \& Zainuddin. 2018. Ilmu Pendidikan Islam. Cet I. Yogyakarta: Deepublish.

Hasanah, F., F., \& Erni, M. 2019. Pengelolaan Pendidikan Karakter Religius Melalui Metode Pembiasaan di Taman Kanak-Kanak. Jurnal: Volume 4 Nomor 1 Maret 2019. Golden Age Tumbuh Kembang Anak Usia Dini.

Hasibuan, A., T., \& Andi, P. 2019. Konsep Pendidikan Abad 21: Kepemimpinan dan Pengembangan SDM SD/MI. Jurnal: Volume 10 Nomor 1. Magistra.

Indana, N., \& Noor, F., Amina, B. 2020. Nilai-Nilai Pendidikan Islam (Analisis Buku Misteri Banjir Nabi Nuh Karya Yosep Rafiqi). Jurnal: Volume 2 Nomor 2 Maret 2020. Ilmuna.

Jempa, N. 2018. Nilai-Nilai Agama Islam. Jurnal: Volume 1 Nomor 2. Pedagogik, Jurnal Ilmiah Pendidikan dan Pembelajaran Fakultas Tarbiyah Universitas Muhammadiyah Aceh.

Lisnawati. 2018. Pengembangan Pembelajaran IPS (Ilmu Pengetahuan Sosial) di 
SD/MI Berbasis Integrasi Interkoneksi. Jurnal: Volume 1 Nomor 3. AlMuta'aliyah.

Maarif, S. 2015. Integrasi Matematika dan Islam dalam Pembelajaran Matematika. Jurnal: Volume 4 Nomor 2 September 2015. Infinity.

Meldina, T., \& Melinedri, \& Alfiana, A., \& Siti, H., H. 2020. Integrasi Pembelajaran IPS pada Kurikulum 2013 di SD. Jurnal: Volume 4 Nomor 1. Ar-Riayah, Jurnal Pendidikan Dasar.

Munawarah, \& Nurhayati, A. 2016. Penerapan Nilai-Nilai Ajaran Islam dalam Pembelajaran Umum. Jurnal: Volume 3 Nomor 2. Istiqra'.

Murfiah, U. 2017. Model Pembelajaran Terpadu di Sekolah Dasar. Jurnal: Volume 1 Nomor 5. Jurnal Pesona Dasar.

Nugroho, B., T., A., \& Mustaidah. 2017. Identifikasi Nilai-Nilai Pendidikan Islam dalam Pemberdayaan Masyarakat pada PNPM Mandiri. Jurnal: Volume 11 Nomor 1 Februari 2017. Jurnal Penelitian.

Pasiska. 2019. Pendidikan Nilai-Nilai Islam di Era Globalisasi. Jurnal: Volume 2 Nomor 1. JRTIE, Journal Of Research and Thought Of Islamic Education.

Rijali, Achmad. 2018. Analisis Data Kualitatif. Jurnal: Volume 17, Nomor 33 JanuariJuni 2018. Alhadharah.

Siska, Y. 2016. Konsep Dasar IPS untuk SD/MI. Cet I. Yogyakarta: Garudhawaca.

Sumaatmaja, N. 2016. Konsep Dasar IPS. Jakarta: Universitas Terbuka.

Susanto, A. 2016. Pengembangan Pembelajaran IPS di Sekolah Dasar. Cet II. Jakarta: Kencana.

Wahid, A. 2019. Integrasi Nilai-Nilai Karakter dalam Pembelajaran IPS di Kelas IV SD Inpres Bertingkat Mamajang 1 Kota Makassar. Prosiding Seminar Nasional Biologi VI Harmonisasi Pembelajaran Biologi Pada Era Revolusi 4.0 